\title{
ANALISIS TERBANG MELUNCUR (GLIDE FLIGHT) PESAWAT TERBANG STTA-12MXA
}

\author{
${ }^{1}$ Bahrun, ${ }^{2}$ Bangga Dirgantara Adiputra \\ ${ }^{1,2}$ Departemen Teknik Dirgantara, Sekolah Tinggi Teknologi Adisutjipto \\ J1. Janti Blok-R Lanud Adisutjipto Yogyakarta \\ 2bangga0885@gmail.com
}

\begin{abstract}
In designing the STTA-12MXA aircraft, analysis of the ability of the glide is one of the important aspects. The analysis was carried out using a numerical approach. There are 2 scenarios used to see the ability of the glide, namely the maximum distance and maximum flight time. The results showed that the maximum distance that the STTA-12MXA aircraft could reach when glide from $13500 \mathrm{ft}$ is $64 \mathrm{~km}$ and for the maximum flight time is 23 minutes.
\end{abstract}

Keyword: glide, STTA-12MXA, distance, time, maximum.

\section{Pengantar}

Pesawat STTA-12MXA merupakan pesawat swayasa pertama yang didesain oleh mahasiswa Teknik Penerbangan Sekolah Tinggi Teknologi Adisutjipto Yogyakarta. Dalam tahap desain tentunya akan menganalisis beberapa hal seperti aerodinamika, struktur, kestabilan, prestasi terbang dll.

Analisis prestasi terbang merupakan bagian yang digunakan untuk melihat kemapuan pesawat dalam setiap fase penerbangan (sesuai dengan misi) yaitu take-off, climb, cruise, loiter, descent, dan landing. Selain hal tersebut, dilakukan juga analisis untuk kemampuan manuever dan glide.

Glide merupakan kemampuan pesawat untuk terbang dalam keadaan dimana semua mesin yang dimiliki oleh pesawat tersebut mengalami kegagalan atau kehabisan bahan bakar. Hal ini sangatlah penting karena dengan mengetahui kemampuan glide pesawat maka pilot akan dapat mengambil keputusan untuk mendaratkan pesawat pada wilayah yang aman. Terdapat 2 skenario dalam pembahasan glide yaitu glide dengan jarak makimum dan glide dengan waktu terbang maksimum.

\section{Metodologi Penelitian}

Terbang Meluncur (Gliding flight) adalah kondisi terbang dimana pesawat dalam melakukan suatu penerbangan berada pada saat ketika pesawat tersebut melayang dan tanpa adanya power yang dihasilkan oleh mesin. Pada kondisi terbang seperti ini, gaya-gaya yang bekerja pada pesawat adalah gaya angkat (lift), gaya hambat (drag) dan gaya berat (weight) seperti yang terlihat pada gambar 1 .

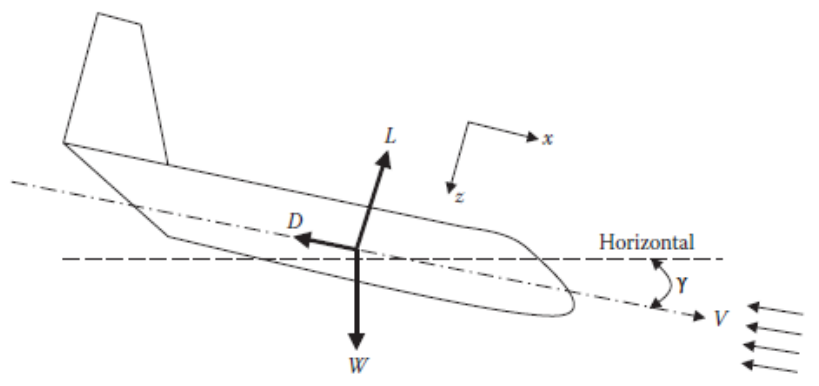

Gambar 1. Diagram Gaya Terbang meluncur kondisi unpowered (sumber : Sadrey, 2017) 
Untuk terbang meluncur dengan kondisi steady unaccelerated, maka persamaan terbang dapat dituliskan sebagai berikut:

$$
\begin{aligned}
& L-W \cos \gamma=0 \\
& L-W \sin \gamma=0
\end{aligned}
$$

Sudut glide $(\gamma)$ dapat diperoleh dengan membagi persamaan (2) dengan persamaan (1) sehingga diperoleh persamaan (3) berikut:

$$
\gamma=\tan ^{-1}\left[\frac{1}{L / D}\right]
$$

Dalam terbang meluncur terdapat 2 skenario (Gambar 2):

1. Meluncur dengan jarak maksimum

2. Meluncur dengan waktu terbang maksimum

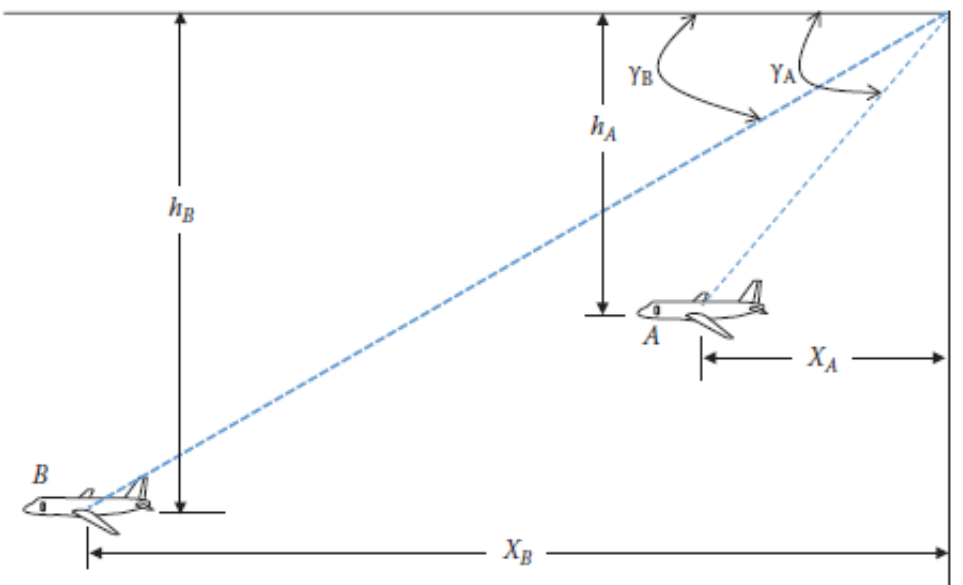

Gambar 2. Dua skenario dalam pengoperasian terbang meluncur (sumber : Sadrey, 2017)

\subsection{Jarak maksimum}

Meluncur dengan capaian jarak maksimum dapat dilakukan jika pesawat tersebut terbang dengan sudut glide minimum $\left(\gamma_{\min }\right)$. Kondisi ini sesuai saat pesawat terbang mengalami kegagalan untuk semua mesin yang dimiliki. Sudut glide minimum dapat dicapai jika pesawat tersebut terbang dengan kondisi rasio lift-to-drag maksimum.

$$
V_{\min }=\tan ^{-1}\left[\frac{1}{(L / D)}\right]
$$

dimana

$$
\begin{aligned}
& \left(\frac{L}{D}\right)_{\max }=\frac{1}{2 \sqrt{K C_{D 0}}} \\
& K=\frac{1}{\pi e A R}
\end{aligned}
$$


Jarak maksimum yang bisa dicapai dalam terbang meluncur untuk kondisi unpowered dapat dihitung dengan menggunakan

$$
d_{\max }=\frac{\Delta h}{\tan \gamma_{\min }}
$$

\subsection{Meluncur waktu terbang maksimum}

Meluncur dengan capaian waktu terbang maksimum pada suatu pesawat dapat terjadi jika terbang dengan sink rate minimum. Sink rate dapat dihitung dengan menggunakan persamaan berikut:

$$
R O S=\sqrt{\frac{2 W}{\rho S\left(C_{L}^{3} / C_{D}^{2}\right)}}
$$

Dari persamaan (5) dapat diketahui bahwa sink rate minimum dapat dicapai apabila nilai $\left(\mathrm{C}_{\mathrm{L}}{ }^{3} / \mathrm{C}_{\mathrm{D}}{ }^{2}\right)$ maksimum. Sehingga persamaan (5) menjadi

$$
\operatorname{ROS}_{\min }=\sqrt{\frac{2 W}{\rho S\left(C_{L}^{3} / C_{D}^{2}\right)_{\max }}}
$$

Waktu maksimum untuk kondisi ini dapat dihitung dengan menggunakan persamaan (8) berikut

$$
t_{\max }=\frac{h}{\operatorname{ROS}_{\min }}
$$

\section{Hasil dan Pembahasan}

Dalam analisis terbang meluncur menggunakan karakteristik pesawat STTA-12MXA yang dapat dilihat pada Tabel 1 .

Tabel 1. Parameter STTA-12MXA

(sumber: Lutfi, M.H., 2015)

\begin{tabular}{|c|l|c|}
\hline No & \multicolumn{1}{|c|}{ Parameter } & Nilai \\
\hline 1. & Berat $(\mathrm{W})$ & $1614 \mathrm{lb}$ \\
\hline 2. & Luas Sayap (S) & $109 \mathrm{ft}^{2}$ \\
\hline 3. & Bilangan Oswald (e) & 0.869 \\
\hline 4. & Koefisien Parasit Drag $\left(\mathrm{C}_{\mathrm{D} 0}\right)$ & 0.01752 \\
\hline 5. & Aspect Ratio (AR) & 6.2 \\
\hline 6. & Ketinggia (h) & $13500 \mathrm{ft}$ \\
\hline
\end{tabular}

Berdasarkan parameter Tabel 1, dilakukan perhitungan untuk kondisi glide dengan jarak maksimum dan waktu maksimum. Dalam perhitungan dapat dilihat bahwa dalam persamaan sink rate terdapat parameter density dimana nilai parameter ini dipengaruhi ketinggian. Sehingga dalam perhitungan nilai density akan mengalami perubahan dengan berubahnya ketinggian. 

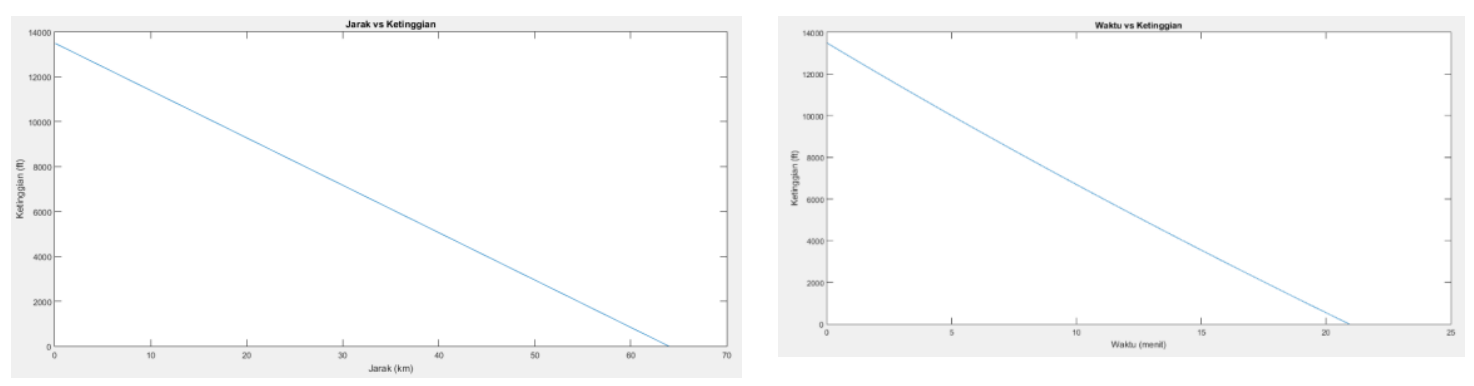

Gambar 4. Jarak dan Waktu pada kondisi Glide dengan jarak maksimum
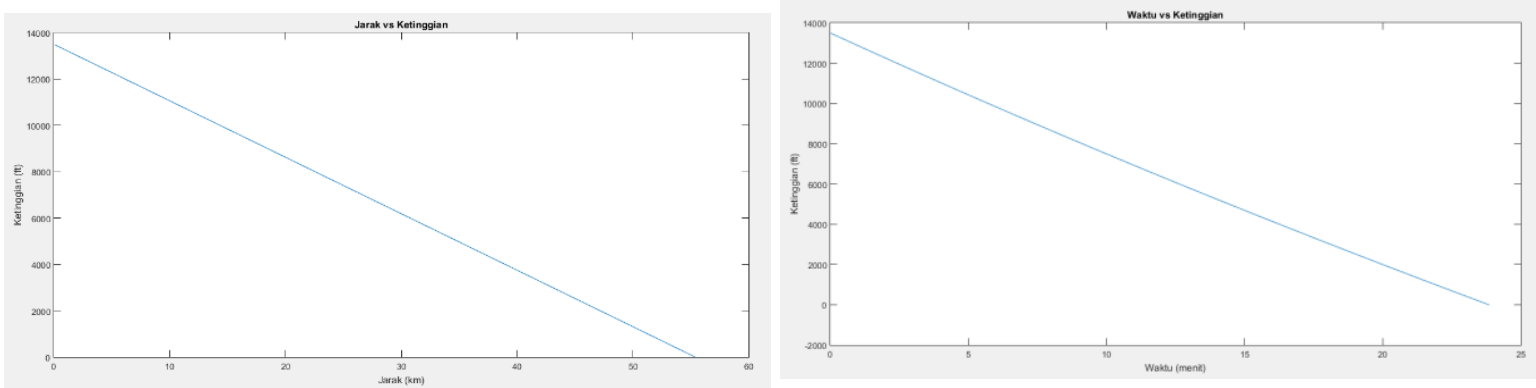

Gambar 5. Jarak dan Waktu pada kondisi Glide dengan waktu terbang maksimum

Tabel 2. Hasil Perhitungan

\begin{tabular}{|c|l|c|c|}
\hline \multirow{2}{*}{ No } & \multicolumn{2}{|c|}{ Parameter } & \multicolumn{2}{|c|}{ Kondisi } \\
\cline { 3 - 4 } & & Jarak Maksimum & $\begin{array}{c}\text { Waktu terbang } \\
\text { maksimum }\end{array}$ \\
\hline 1. & Sudut Glide $(\gamma)$ & $3.6^{\circ}$ & $4.2^{\circ}$ \\
\hline 2. & Jarak & $64 \mathrm{~km}$ & $55 \mathrm{~km}$ \\
\hline 3. & Waktu & 20 menit & 23 menit \\
\hline
\end{tabular}

\section{Kesimpulan}

Analisis terhadap terbang meluncur pesawat STTA-12MXA telah selesai dilakukan. Pada skenario dengan terbang jarak maksimum, pesawat STTA-12MXA dapat terbang meluncur dari ketinggian $13500 \mathrm{ft}$ dengan unpowered diperoleh jarak sebesar $64 \mathrm{~km}$ dan waktu terbang selama 20 menit. Sedangkan untuk skenario dengan terbang waktu maksimum dan dengan kondisi yang sama diperoleh jarak sebesar $55 \mathrm{~km}$ dan waktu terbang maksimum selama 23 menit.

\section{Daftar Pustaka}

[1] Lutfi, M.A. (2015). Perancangan Konseptual Pesawat Swayasa STTA-12MXA (Multirole Experimental Aircraft) Tandem Seater Single Engine Reciprocating Engine. Skripsi Sekolah Tinggi Teknologi Adisutjipto. Yogyakarta.

[2] Anderson, John D. (2012). Introduction to Flight ${ }^{\text {th }}$. Mc GrawHill. New York.

[3] Sadrey, M.H. (2017). Aircraft Performance: An Engineering Approach. CRC Press. America.

[4] Anderson, John D. (2010). Aircraft Performance and Design. Mc GrawHill. New York.

[5] Ruijgork, G.J.J. (1990). Elements of Airplane Performance. Faculty of Aerospace Engineering Delft University of Technology. Netherlans. 